\title{
Allergic Rhinits: Prevalence And Associated Factors Among Students of A Secondary School in South-west Nigeria.
}

\author{
Uche-Okonkwo K. $C^{1}$,Akinola M. $A^{1}$,Jagun O.O. $A^{2}$,Oladeji S. $M^{1}$,Johnson K.J ${ }^{1}$ \\ ${ }^{I}$ Otorhinolaryngology Unit, Department Of Surgery, Babcock University Teaching Hospital, Ilishan-Remo, \\ Ogun State. \\ ${ }^{2}$ Ophthalmology Unit, Department Of Surgery, Babcock University Teaching Hospital, Ilishan-Remo, Ogun \\ State.
}

\begin{abstract}
Background: Allergic rhinitis is a symptomatic disorder following exposure to trigger particles. It is frequently associated with other systemic manifestations of allergy as well as asthma and is known to have significant effects on the quality of life of sufferers.

Methodology: A cross-sectional survey conducted amongst students in a secondary school in South-West Nigeria.A modified I.S.A.A.C questionnaire, was administered with questions assessing the presence and severity of allergic symptoms, as well as the possible risk factors. Data collected was analyzed using SPSS version 21.

Results: Six hundred and twenty-one [621] students were recruited for this study. The prevalence of allergic rhinitis was $56.7 \%$, of which $28.8 \%$ had accompanying itchiness of the throat, as well as itchiness, watering and redness of the eyes. Dust (33.0\%) and Cold (15.6\%) were the commonly implicated allergens with symptoms peaking in the months of October and November. Symptoms of allergic rhinitis were found in $79.1 \%$, $73.9 \%$ and $64.2 \%$ of respondents with symptoms of physician diagnosed asthma, allergic conjunctivitis and a family history of allergy respectively. Only $7.5 \%$ of respondents admitted to be significantly affected by their symptoms while 15\% had missed a class in the preceding 12 months due to these symptoms.

Conclusion: Allergic rhinitis co-exists with other forms of allergy: dermatitis, conjunctivitis and asthma. The commonest identified allergens in this environment are dust and cold, with symptoms most severe towards the end of the rainy season and beginning of the harmattan.
\end{abstract}

Keywords: Allergy, Rhinitis, Associated factors, Quality of life.

\section{Introduction}

Allergic rhinitis refers to a symptomatic disorder of the nose induced by immunoglobin $\mathrm{E}$ (IgE) mediated inflammation of the membranes of the nose following allergen exposure [1]. The allergens usually compriseof ordinary particles ever-present in the environment (to varying degrees depending on the prevailing weather and climate) such as dust, pollen, flower, animal fur/dander, smoke, mold, and insects. [2, 3, 4, 5]. The immunoglobulin- mediated reaction is also known as antibodies. Allergy has been identified as the most common cause of rhinitis and allergic rhinitis the most common allergic disorder as well as the most common chronic disease in the world [6]. It is common in childhood, adolescence and early adult yearsin persons of all races. The mean age of onset is 8-11years, peaking by the age of 20 years but can occur at any age[7].

The pattern of development and severity of symptoms, which invariably co-relates with the seasonal prevalence of specific aero-biological trigger factors, forms the basis of classification of this disease into seasonal, perennial or mixed, or more recently into mild-intermittent, moderate-severe intermittent, mild persistent, and moderate-severe persistent. While allergic rhinitis itself is not life-threatening, (unless accompanied by severe asthma or anaphylaxis), morbidity from the condition can be quite significant. The disease often co-exists with other disorders such as asthma, atopic dermatitis, eczema and nasal polyps. Other complications that lead to increased morbidity include otitis media, acute sinusitis, chronic sinusitis and Eustachian tube dysfunction. [1,3,11]. This study aims to determine the prevalence of allergic rhinitis amongst students of Babcock high school as well as its associated factors and impact on their daily activities.

\section{Methodology}

This was a cross-sectional study carried out among the students of Babcock university High school. Babcock University High school is a co-educational institution owned and operated by the Seventh Day Adventist church. It is located within the campus of Babcock University. The university itself occupies 140 hectares of land mass situated in Ilishan-Remo, a sleepy town in the Ijebu-Remo division of the old western region and present day Ogun state in Nigeria. It is roughly midway between the cities of Lagos and Ibadan with a population of 118,735 according to the 2006 national population census. All the students who gave consent 
were included in this study with no exclusion criteria. A brief educational session on clarification and definition of terms from the questionnaire was held in the school hall.Thereafter the questionnaires were completed by the student and collected data wereanalyzed using the statistical software for social sciences version 21 . Statistical significance was said to have been achieved if the p-value is less than 0.05 .

\section{Results}

Six hundred and twenty-one respondents with a mean age of 13.5 \pm 1.25 years [range: 9-18 years] participated in the study. Majority (88.7\%) of the respondents were females and $97.7 \%$ of Fathers and $96.8 \%$ of mothers of the respondents had completed tertiary education (Table 1).

Three hundred and fifty-two $(56.7 \%)$ respondents had symptoms suggestive of allergic rhinitis,such as persistent sneezing, itchiness and a runny nose over the past 12 months prior to the study.From this group, $28.8 \%$ had accompanying itchiness of the throat as well as itchiness, watering and redness of the eyes.

About half of the respondents $(50.4 \%)$ said their nasal symptoms did not affect their daily activities compared to $7.25 \%$ who admitted that their symptoms interfered a lot with their daily activities. The rest $(42.35 \%)$ had responses varying from a little to moderate interference in daily activities (Table 2). Only $15 \%$ of respondents had ever missed a class as a result of these symptoms. A significant majority of respondents $(92.6 \%)$ affirmed that they did not feel these symptoms affected their academic performance.

$30.6 \%$ of respondents believed their symptoms to be most severe in the month of November. August, September and October also showed significant symptom severity [15.6\%, 18.5\%, and 29.0\% respectively]. Allergy to allergens was documented amongst $78.3 \%$ of respondents, with dust and cold being the most commonly identified allergens $(33.0 \%$ and $15.6 \%$ respectively). Animal fur and pollen were the least popular allergens $(1.6 \%$ and

\section{$1.1 \%$ respectively).}

$35.7 \%$ of respondents had recurrent episodes of redness and itchiness of the eyes within the last 12 months, with symptoms showing peak severity in the month of October (28.4\%) but also high in November (25.4\%), July (19.3\%), August (17.3\%) and September (16.2\%).

The prevalence of physician-diagnosed asthma amongst the study population was $6.9 \%$. About a quarter $(25.8 \%)$ of respondents had a positive family history of asthma, while $38.6 \%$ had a family history of other allergies.

Table 1: Socio-demographic distribution of the respondents

\begin{tabular}{|l|l|l|}
\hline Variable & Frequency & Percentages \\
\hline Age & & \\
\hline 9-13years & 398 & 64.1 \\
\hline 14-18years & 223 & 35.9 \\
\hline Sex & & \\
\hline Male & 70 & 11.3 \\
\hline Female & 551 & 88.7 \\
\hline Father's education Level & & \\
\hline No formal education & 1 & 0.2 \\
\hline Primary & 1 & 0.2 \\
\hline Secondary & 12 & 1.9 \\
\hline Tertiary & 607 & 97.7 \\
\hline Mother's educational level & & \\
\hline Primary & 2 & 0.3 \\
\hline Secondary & 18 & 2.9 \\
\hline Tertiary & 601 & 96.8 \\
\hline
\end{tabular}

Table 2: Showing the distribution of symptoms and risk-factors

\begin{tabular}{|c|c|c|}
\hline Symptom & Frequency & Percentage \%) \\
\hline \multicolumn{3}{|l|}{ Persistent sneezing, runny nose, blocked nose in the last 12 months } \\
\hline YES & 352 & 56.7 \\
\hline NO & 269 & 43.3 \\
\hline \multicolumn{3}{|l|}{$\begin{array}{l}\text { Itchy rash coming and going for at least } 6 \text { months- } \\
\text { Present anytime in the past } 12 \text { months }\end{array}$} \\
\hline YES & 186 & 30.0 \\
\hline $\mathrm{NO}$ & 435 & 70.0 \\
\hline \multicolumn{3}{|l|}{ Recurrent redness and itchiness of the eyes within the last 12 months } \\
\hline YES & 222 & 35.7 \\
\hline NO & 399 & 64.3 \\
\hline \multicolumn{3}{|l|}{ Physician-diagnosed Asthma } \\
\hline YES & 160 & 25.8 \\
\hline NO & 460 & 74.2 \\
\hline
\end{tabular}




\begin{tabular}{|c|c|c|c|c|c|}
\hline \multirow{2}{*}{$\begin{array}{l}\text { Have you had a problem with persistent sneezing, runny nose or } \\
\text { blocked nose } \\
\text { in the past } 12 \text { months }\end{array}$} & \multicolumn{2}{|c|}{ YES } & \multicolumn{2}{|c|}{$\mathrm{NO}$} & \multirow[t]{2}{*}{ P-Value } \\
\hline & $\mathrm{N}$ & $\%$ & $\mathrm{n}$ & $\%$ & \\
\hline Father's educational level & & & & & 0.688 \\
\hline No formal education & 0 & 0.0 & 1 & 100 & \\
\hline Primary & 1 & 100 & 0 & 0.0 & \\
\hline Secondary & 6 & 50 & 6 & 50.0 & \\
\hline Tertiary & 345 & 56.8 & 26.2 & 43.2 & \\
\hline Mother's educational level & & & & & 0.905 \\
\hline Primary & 1 & 50.0 & 1 & 50.0 & \\
\hline Secondary & 11 & 61.1 & 7 & 38.9 & \\
\hline Tertiary & 340 & 56.6 & 261 & 43.4 & \\
\hline Redness and itchiness of the eyes in the past 12 months & & & & & $<0.0001$ \\
\hline Yes & 164 & 73.9 & 58 & 26.1 & \\
\hline No & 188 & 47.1 & 211 & 52.9 & \\
\hline Itchy rash coming and going for at least 6 months & & & & & $<0.0001$ \\
\hline Yes & 103 & 71.5 & 41 & 28.5 & \\
\hline No & 249 & 56.7 & 228 & 43.3 & \\
\hline Physician-diagnosed asthma & & & & & 0.002 \\
\hline Yes & 34 & 79.1 & 9 & 20.9 & \\
\hline No & 318 & 55.0 & 260 & 45.0 & \\
\hline Family history of Allergy & & & & & 0.003 \\
\hline Yes & 154 & 64.2 & 86 & 35.8 & \\
\hline No & 198 & 52.0 & 183 & 48.0 & \\
\hline
\end{tabular}

Table 3: Symptoms of Allergic rhinitis and suspected associated factors

\section{Discussion}

Over half $(56.7 \%)$ of the students had symptoms suggestive of allergic rhinitis, similar to the $54.1 \%$ observed by Falade [12] et al., in Ibadan. However, the rate was higher than the prevalence rate of $40.5 \%$ and $29.6 \%$ observed by Sogebi [14] et al in Sagamu., and Desalu [13] at al at Ilorin respectively.

However, we also discovered that symptoms were more prevalent in respondents whose parents had not received university level education, a variable we could not objectively assess given that most [ approx. $97 \%$ ] parents in our study had completed university level education.

House dust was found to be the commonest allergen in this study, followed by allergy to cold. This finding was corroborated by Desalu et al.,who also found dust to be the commonest allergen in their research. Bauchau et al., [15], however, in a similar study carried out in Western Europe, found grass pollen as the commonest implicated allergen to the development of allergic rhinitis symptoms, followed by dust mites. This difference can probably be explained by the difference in aero-biological factors pertaining to the two, very different climates.

Concerning the prevalence of allergic dermatitis and physician diagnosed asthma amongst study population, Falade found $18.4 \%$ had physician-diagnosed asthma, and $26.1 \%$ had allergic dermatitis which is much lower than this study population with $30.0 \%$ and $25.8 \%$ respectively.

Allergic rhinitis was found to frequently co-exist with asthma, a finding shared by independent studies in Europe [16 - 21] as well as the I.S.A.A.C study [22]. A significant percentage of respondents with allergic rhinitis also experienced recurrent itchiness and redness of the eyes, and symptoms of persistent sneezing and runny nose over the previous 12 months with a positive family history of allergy. This is corroborated by similar findings in Europe [23-28] as well as by Falade et al in Ilorin, Nigeria [12], suggesting that allergic rhinitis is a manifestation of an underlying atopic pathology, and therefore invariably co-exists with other atopic manifestations such as asthma, allergic conjunctivitis and allergic dermatitis. Comparison of variables concerning family history of allergy, physician-diagnosed asthma, history suggestive of allergic dermatitis, allergic conjunctivitis with positive responses for history suggestive of allergic rhinitis showed a statistically significant relationship which suggest that patients with a family history of allergy, physician-diagnosed asthma, allergic dermatitis or allergic conjunctivitis were more likely to develop allergic rhinitis.

In studying the impact of such symptoms on the daily lives of our respondents, we found that daily activities were significantly affected by allergic symptomsin only $7.25 \%$ of subjects. While $15 \%$ of respondents had missed a class as a result of these symptoms, and $7.4 \%$ felt their symptoms affected their academic performance in some ways. This values are much lower than documented by AbdulRahman [7] in the middle East where $72 \%$ of individuals suffered significant hindrance in work/job performance and $56 \%$ had missed work/school as a result of symptoms of allergic rhinitis in the previous 12 months. 


\section{Conclusion}

Allergic rhinitis is a commonly seen disorder amongst teenagers and young adults in this environment. It frequently co-exists with other forms of allergy- dermatitis, conjunctivitis and asthma. The commonest identified allergens in this environment is dust and cold, with symptoms most severe at the beginning of the harmattan season.

\section{References}

[1]. Togias A.G. (2000) Systemic Immunologic and Inflammatory aspects of Allergic Rhinitis. Journal of Allergy and Clinical Immunology, 106(5), 247-250.

[2]. Gastek [package insert]. Whitehouse station NJ.Merk\&Co. Inc. April 2014

[3]. Kiyohara C, Tanaka K, Miyake Y. (2008) Genetic susceptibility to atopic dermatitis. Allergol International. 57(1): 39-56

[4]. Matsui E.C, Simins E, Rand C, Butz A, Buckley TJ, Breysse P. (2005). Airborne mouse allergen in the homes of inner city children with asthma. Journal of Allergy and Clinical Immunology. 115(2): 358-363

[5]. Morgan W.J, Crain E.F, Gruchalla R.S, O’Connor G.T, Kattan M, Evans R. (2004) Results of a home based environmental intervention among urban children with asthma. New England Journal of Medicine. 351 (11). 1068-1080.

[6]. Bousquet J, Khaltaev N, Cruz A, Dehburg J, Fokkens W, Togias A et al. (2006) Allergic Rhinitis and its impact in Asthma (A.R.I.A) A.R.I.A workshop report update. http://www.whiar.org.

[7]. Abdulrahman H, Hadi U, Tarrat H, Gharagozlou M, Kamel M, Soliman A, Hamad W.A, Hanna K.M, Moustafa B.E, Omrani M, et al. (2012) Nasal allergies in the middle Eastern population: Results from the 'Allergies in Middle East Survey". American Journal of Rhinology and Allergy. 26(1), 3-23.

[8]. Skoner D.P. (2001) Allergic Rhinitis: Defintion, Epidemiology, Pathophysiology, Detection and Diagnosis. Journal of Allergy and Clinical Immunology.108 (1), 2-8

[9]. Walls A.F, He S, Buckeley M.G, McEven A.R. (2001) Roles of the mast cell and basophils in Asthma. Clinical and Experimental Allergy.68(1).

[10]. Haberal I, Corey J.P. (2003) The role of leukotrienes in nasal allergy. Otorhinolaryngology, Head and Neck Surgery. 129(3) 249257.

[11]. Druce N, Reed C.E, Ellis E.F, Adkinson N.F Jr, Yuriginger J.W, Busse W.W. (1998). Allergy and Non-Allergic Rhinitis. Allergy; Principles and practice. $5^{\text {th }}$ ed. St. Louis, 1005-16

[12]. Falade A.G, Olawuyi F, Osinusi K, Onadeko B.O. (1998) Prevalence and severity of symptoms of Asthma, Allergic RhinoConjunctivitis and Atopic Eczema in secondary school children in Ibadan, Nigeria. East African Medical Journal. 75(1), 695-698.

[13]. Desalu O.O, Salami A.K, Ikeh K.R, OluboyoP.O. (2009). Prevalence of self-reported allergic rhinitis and its relationship with asthma among adult Nigerians. Journal of investigational allergology and clinical immunology. 19(6), 474-480.

[14]. Sogebi O, Oyewole E. (2006) Rhinosinusitis: Clinical Features seen in Sagamu, Nigeria. The Internet Journal of Otorhinolarynology. 6(2)

[15]. Bauchau V, Durham S.R. (2004) Prevalence and rate of diagnosis of allergic rhinitis in Europe. European respiratory journal. 24 (5), 758-764.

[16]. Settipane R.J, Hagy G.W, Settipane G.A. (1994). Long term risk factors for developing asthma and allergic rhinitis, a 23year followup study of college students. Allergy and Asthma Proceedings.15(1) 21-25

[17]. Stefano G, Duane S, Fernando D.M, Robert A.B. (2002) Rhinitis as an independent risk factor for Adult Onset Asthma. Journal Allergy and Clinical and Immunology. 109 (3), 419-425.

[18]. Munoz-Lopez F. (2003) Rhinitis as a precursor for asthma. Allergol. Immunopathol. 31(6) 297-302

[19]. Blaiss M.S. (1999) Quality of Life in allergic Rhinitis. Annals of Allergy Asthma Immunol. 83(5). 449-454.

[20]. Leynaert B, Neukirch C, Liard R, Bousquet J, Neukirch F. (2000) Quality of Life in allergic rhinitis and asthma: A population based study of young adults. American Journal of Respiratory Critical Care Medicine. 162(1) 1391-1396.

[21]. Ryan M.W (2008) Asthma and Rhinits: Co-Morbidities. Otolaryngologic clinics of North America. 41(2). 283-295.

[22]. Beasley R. et al. (1998). Worldwide variation in prevalence of symptoms of asthma, allergic rhino-conjunctivitis and atopic eczema. I.S.A.A.C. The Lancet. 351 (9). 1225-1232

[23]. Asher M.I, Montefort S, Bjorksten B et al. (2007). Worldwide trends in the prevalence of symptoms of Asthma, Allergic RhinoConjunctivitis and Eczema in Childhood. I.S.A.A.C phases one and three repeat multicountry cross-sectional surveys. Lancet. 368. 733-743

[24]. Braunstahl G.J. (2009). United airway concept: What does it teach us about systemic inflammation in airway disease? Proceedings of the American Thoracic Society. 6(1), 652-654.

[25]. Salib R.J, Drake-Lee A, Howard P.H. (2003). Allergic rhinitis; Past, Present and the future. Clinical Otolaryngology and allied sciences. 291-303

[26]. Braun-Fahrlanderch, Wuthrich B, Gassner M, Grize L, Semhauser F.H, Varonier HS, Vuille J.C. (1997). Validation of a rhinitis questionnaire (I.S.A.A.C core questions) in a population of swiss school children visiting the school health services. Paediatric Allergy and Immunology. 8(1),75-82.

[27]. Ricci G, Patrizi A, Baldi E, Menna G, Tabanelli M, Masi M. (2006). Long term follow-up of atopic dermatitis; Retrospective analysis of related risk factors and association with concomitant allergic diseases. Journal of the American Academy of Dermatology. 55(1), 765-771.

[28]. Guerra S, Sherill DL, Maertinez FD, Barbee RA. (2002). Rhinitis as an independent risk factor for adult-onset asthma. J Allergy ClinImmunol. 109(3):419-25 